\title{
Soursop leaf extract increases neuroglia and hepatic degeneration in female rats
}

\author{
Ety Sari Handayani*, Zainuri Sabta Nugraha*, Ika Fidianingsih**, \\ and Prilly Raleka Pahlevawati****
}

\begin{abstract}
\section{BACKGROUND}

Soursop leaf contains annonaceous acetogenins and alkaloids. The acetogenins act as inhibitors of mitochondrial complex I, suppress ATP production and cause cell degeneration, whereas the alkaloids act as neurotoxins. Neuronal degeneration will be followed by an increase in neuroglia (gliosis). Hepatic clear cell foci represent the morphology of liver degeneration. The purpose of this study was to evaluate the effect of soursop leaf extract on number of neuroglia brain gliosis and hepatic clear cells in female rats.
\end{abstract}

\section{METHODS}

This study was an experimental study with a post-test only control group design. Ten female Sprague-Dawley strain rats were divided into one control and one treatment group. The control group was gavaged with distilled water, while the treatment group was gavaged with aqueous soursop leaf extract at a dose of $1000 \mathrm{mg} / \mathrm{kgBW} /$ day for 90 days. Rat brain tissue samples were taken at day 91 with a transcardial perfusion technique. The number of neuroglia in rat cerebral cortex, hippocampus, substantia nigra, and nucleus accumbens and the number of hepatic clear cells were determined. Independent t-test was used to examine the differences in the numbers of neuroglia and hepatic clear cells between control and treatment groups.

\section{RESULTS}

The results of independent t-test analysis found a significant difference in the number of neuroglia in the cerebral cortex $(\mathrm{p}=0.015)$ and nucleus accumbens of the rats $(\mathrm{p}=0.030)$, and significant differences in the number of hepatic clear cells $(\mathrm{p}=0.029)$.

\section{CONCLUSIONS}

Aqueous soursop leaf extract orally increases neuroglia of the cerebral cortex and nucleus accumbens, and hepatic degeneration in female rats.

\section{*Anatomy Department,}

Faculty of Medicine,

Islamic University of Indonesia,

Yogyakarta

**Histology Department,

Faculty of Medicine,

Islamic University of Indonesia,

Yogyakarta

***Medical Profession Program,

Faculty of Medicine,

Islamic University of Indonesia,

Yogyakarta

\section{Correspondence}

dr. Ety Sari Handayani, M.Kes

Anatomy Department,

Faculty of Medicine,

Islamic University of Indonesia

Jl. Kaliurang Km14,5 Yogyakarta

Phone: +62274-898470 ext. 2033

Fax: +62274-898470 ext. 2007

Email: eshyasser@yahoo.co.id

Univ Med 2015;34:17-24

DOI: $10.18051 /$ UnivMed.2016.v35.17-24 pISSN: 1907-3062 / eISSN: 2407-2230

This open access article is distributed under

a Creative Commons Attribution-Non Commercial-Share Alike 4.0 International License

Keywords: Soursop leaf, degeneration, brain, liver, female rats 


\section{Ekstrak air daun sirsak meningkatkan neuroglia dan degenerasi hepar pada tikus betina}

\section{ABSTRAK}

\section{LATAR BELAKANG}

Daun sirsak mengandung senyawa aktif Annonaceous acetogenins dan alkaloid. Acetogenin sebagai inhibitor kompleks I mitokondrial menurunkan produksi ATP menyebabkan degenerasi sel. Senyawa alkaloid bersifat neurotoksin. Degenerasi neuron ditandai dengan peningkatan neuroglia (gliosis). Clear cell focus hepatosit adalah gambaran morfologi degenerasi hepar. Tujuan dari penelitian ini adalah untuk menilai efek ekstraks air daun sirsak terhadap jumlah neuroglia dan jumlah clear cell focus hepatosit pada tikus betina.

\section{METODE}

Rancangan penelitian eksperimental ini adalah post test only control group design, menggunakan 10 ekor tikus betina galur Sprague-dawley, terbagi menjadi dua kelompok yaitu kelompok kontrol dan perlakuan. Kelompok kontrol mendapatkan sondase aquades, dan kelompok perlakuan mendapatkan ekstrak air daun sirsak dosis 1000 mg/kgBB/hari selama 90 hari. Pada hari ke 91, jaringan otak tikus diambil dengan menggunakan transcardial perfusion technique. Jumlah neuroglia diamati pada cortex cerebri, hippocampus, substansia nigra dan nucleus accumbens tikus. Uji t-independen digunakan untuk menguji adanya perbedaan jumlah neroglia dan haposit hepar antara kelompok kontrol dan perlakuan.

\section{HASIL}

Analisis dengan uji $t$ independen menunjukkan adanya perbedaan bermakna antara kedua kelompok perlakuan, jumlah neuroglia di cortex cerebri $(p=0,015)$ dan nucleus accumbens tikus $(p=0,030)$, serta terdapat perbedaan bermakna clear cell focus hepatosit $(p=0,029)$.

\section{KESIMPULAN}

Pemberian ekstrak air daun sirsak secara oral meningkatkan neuroglia di cortex cerebri dan nucleus accumbens otak serta degenerasi hepar pada tikus betina.

Kata kunci : Daun Annona muricata, degenerasi, otak, hepar, tikus betina

\section{INTRODUCTION}

Annona muricata has been used for the prevention and treatment of cancer. ${ }^{(1)}$ The phytochemicals present in the plant possess antioxidant activities, which can be used in the prevention or treatment of many diseases, including cancer. However, several species of the Annonaceae family, including A. muricata, have also been targeted for investigation due to appurtenant substances among the acetogenins. ${ }^{(2)}$

Annonaceous acetogenins have cytotoxic properties that can inhibit the mitochondrial complex I enzyme. Inhibition of this enzyme significantly reduces the production of energy (ATP), cause cancer cell death. ${ }^{(1,3)}$ However, the inhibitory effect may also occur in normal cells, particularly those with high ATP requirements, such as the brain, liver, and kidney. Various studies show that the soursop plant exerts side effects on healthy cells. Administration for 28 days of purified acetogenins derived from soursop plant roots, was capable of causing degeneration of substantia nigra neurons in the rat brain, with symptoms similar to parkinsonism. Annonacin can cause cortical 
neuronal death in in-vitro experiments. ${ }^{(4)}$ Inhibition of mitochondrial complex I causes a reduction in ATP associated with increased tau protein. $^{(5)}$

Administration of annonacin does not always result in toxicity. Mutant R406W mice had a decreased number of cortical, parietal and hippocampal neurons in comparison with nonmutant mice. ${ }^{(6)}$

The liver is composed of hepatocytes that are arranged radially around the central vein. The cytoplasm of hepatocytes contain 2000 mitochondria. The large number of mitochondria in hepatocytes is associated with the high performance of the liver in the body. In rat hepatocytes receiving ethanolic leaf extract of the sugar apple (Annona squamosa), another member of the Annonaceae family, there was an increase in their apoptotic index in HE stained preparations. ${ }^{(7)}$

The brain and the liver are vital organs in the body. The performance of the brain and the liver is highly dependent on the availability of ATP in the cells. Physiologically, if the decrease in ATP production occurs in the long run, the cells may degenerate and die by necrosis or apoptosis. ${ }^{(8-10)}$ Damage to the neurons will be followed by an increase in the number of neuroglia (gliosis). Liver damage can result in hepatic clear cell foci. ${ }^{(11)}$

Based on these facts, the objective of this study was to evaluate the effect of soursop leaves extract on brain gliosis and hepatic clear cell foci in female rats.

\section{METHODS}

\section{Research design}

The design of this research was an experimental posttest only control group. The study was conducted from April until October 2013 at the Pharmacy Laboratory and Histology Laboratory, Islamic University of Indonesia, the Integrated Research and Testing Laboratory, Gadjah Mada University (LPPT UGM) and the Microanatomy Laboratory, Faculty of Veterinary
Medicine, Gadjah Mada University (FKH UGM).

\section{Animals and experimental procedure}

The animals used in this study were female rats (Rattus norvegicus of the Sprague-Dawley strain) that had met the inclusion and exclusion criteria. The rats were reared in the Pharmaceutical Laboratory, Islamic University of Indonesia. Inclusion criteria for this study were healthy 3-month old female rats without any defects, of 175-250 g body weight, and normal hemoglobin and SGOT levels. Exclusion criteria were pain and disability in the rats during the course of the study. The samples used were 10 rats that were divided into 2 groups: the control and the treatment group, each group consisting of 5 rats. Sample size determination was according to the guidelines of Lwanga and Lemeshow. The treatment group was gavaged with aqueous soursop leaf extract at $1000 \mathrm{mg} /$ $\mathrm{kgBW} /$ day given in volumes of $2 \mathrm{~mL} /$ day. The control group was gavaged with distilled water at a dosage of $2 \mathrm{~mL} /$ day. The interventions were performed for 90 days.

\section{Preparation of soursop extract}

Soursop leaves were selected from the $4^{\text {th }}$ to $6^{\text {th }}$ level branches of the trees. Preparation of the aqueous soursop leaf extract was done in the Integrated Research and Testing Laboratory, Gadjah Mada University.

\section{Preparation of brain tissue samples}

Rat brain tissue samples were taken at day 91 with a transcardial perfusion technique. The samples were then made into paraffin blocks and HE stained sections. The parts of the rat brain that were studied comprised the cerebral cortex, hippocampus, nucleus accumbens and substantia nigra. Observations on vacuolization and neuroglial number were made using an Olympus CX21 light microscope with an Optilab camera and linked to a computer containing the Optilab Viewer software program. In each sample, all fields of view were taken. In one field of view 
were taken all neuroglia located to the right of the left border of the photo frame and above the lower limit of the photo frame. The results were read by a single person. The neuroglia were studied morphologically. Oligondendrocytes have dark-colored round or oval nuclei with darkcolored cytoplasms. Microglia have dark-colored bean-shaped or irregular nuclei and dark-colored cytoplasms that are lighter in color than those of oligodendrocytes. Astrocytes have pale nuclei.

Rat liver tissue samples were taken on day 91 prior to the transcardial perfusion technique. The microscopic features of focal hepatocyte lesions were observed in their cytoplasms. The number of hepatic clear cells was determined on HE stained sections, in all fields of view in each section. The main microcopic feature was the nearly white color of the unstained cytoplasm of the hepatocytes. The observation were made using an Olympus CX21 light microscope with an Optilab camera and linked to a computer containing the Optilab Viewer software program.
In each sample, all fields of view were taken. The cytoplasmic vacuolization was observed at $1000 \mathrm{x}$ total magnification (using a $100 \mathrm{x}$ objective lens and a $10 \mathrm{x}$ ocular lens). After microscopic observation, the morphology was recorded as images of 640x480 pixels using the Optilab Viewer.

\section{Statistical analysis}

Independent t-test was used to determine the differences in the numbers of neuroglia and hepatic clear cells between control and treatment groups.

\section{Ethical clearance}

This study was reviewed by the Ethical Clearance Committee for preclinical research, Integrated Research and Testing Laboratory, Gadjah Mada University (LPPT UGM) and obtained ethical clearance under No.139/KECLPPT/III/2014.
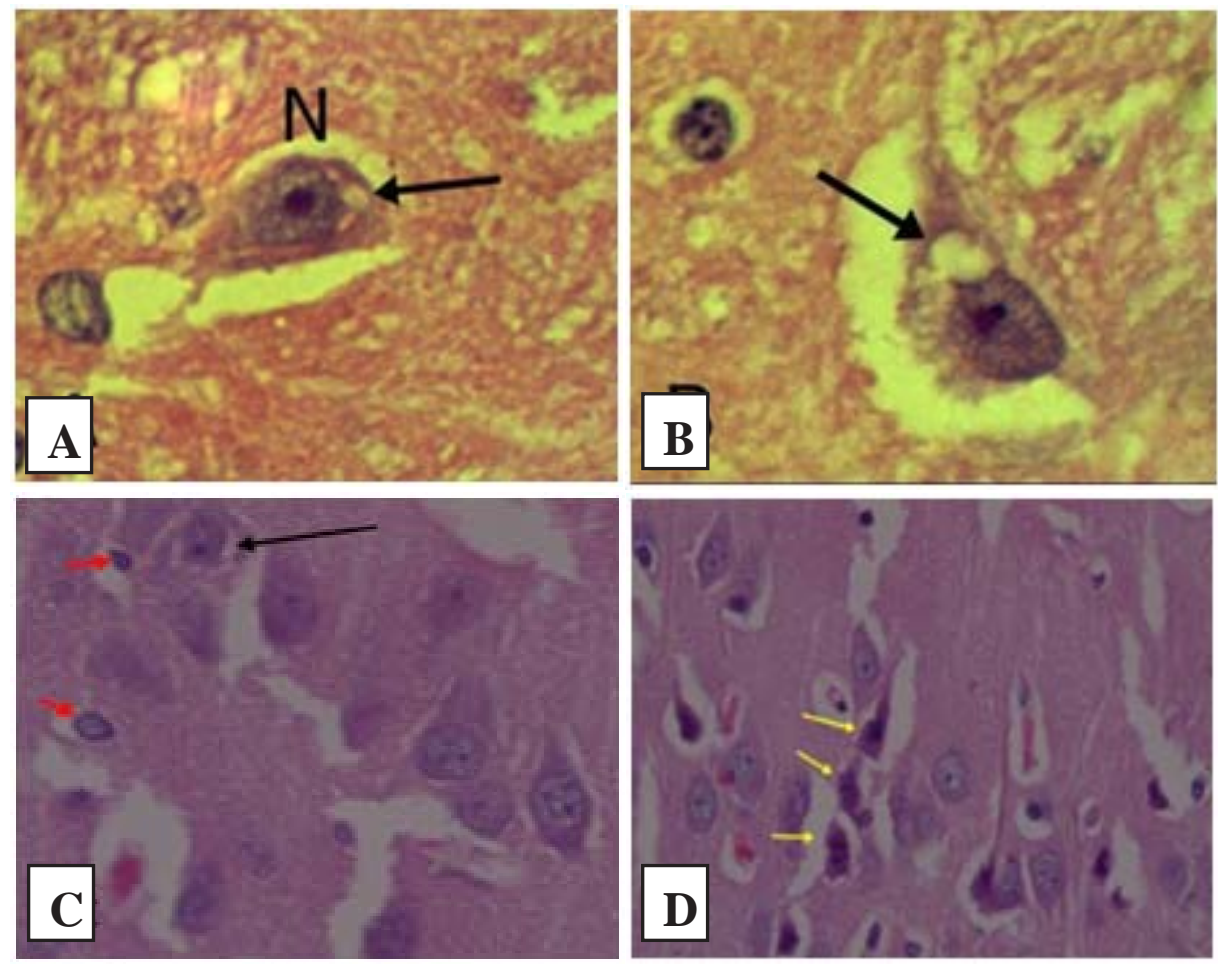

Figure 1. Vacuolization (black arrows) in substantia nigra neurons (A, B), cytoplasmic vacuolization of neurons (black arrows), neuroglia (red arrows) in the hippocampus (C), necrosis of neurons (pycnotic nuclei) (yellow arrows) in the hippocampus (D) (HE staining at 1000x magnification). 

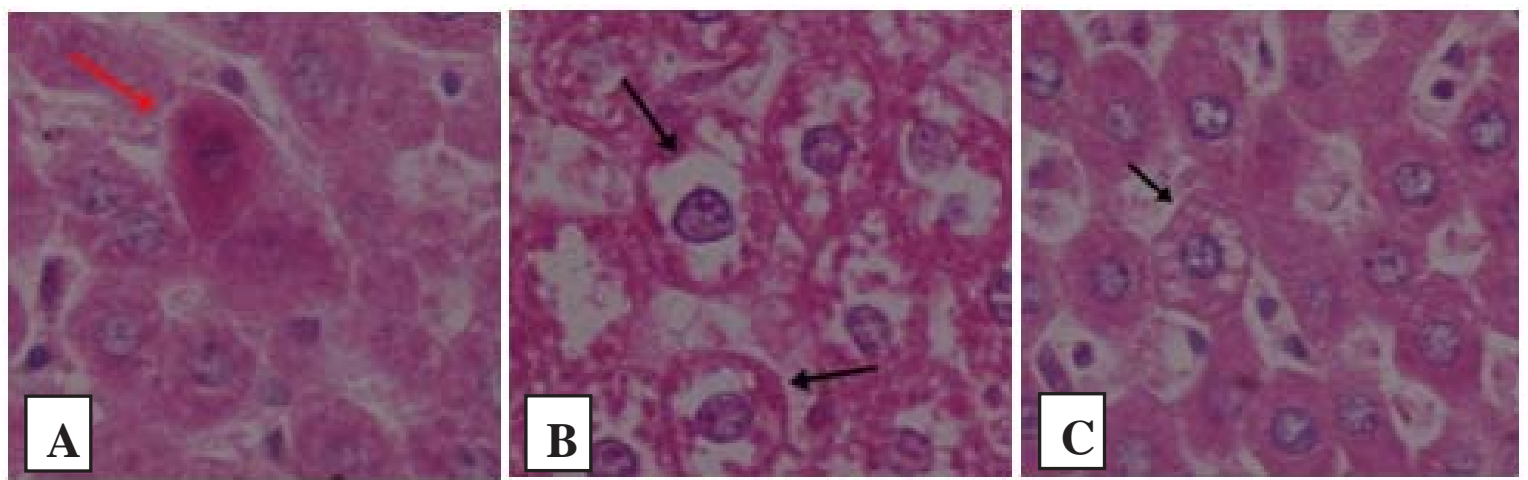

Figure 2. A. Acidophilic hepatocyte (red arrow), B. Hepatic clear cells (black arrows), C. cytoplasmic vacuolization (black arrow) (HE staining at 1000x magnification)

\section{RESULTS}

The present study used 10 rats assigned randomly to the control and treatment groups. The rats were in healthy condition and during the study no rats were disabled or died.

Overall, the administration of the aqueous extract of soursop (Annona muricata) leaves orally for 90 days resulted in neuronal degeneration in the rat substantia nigra and neuronal vacuolization in the hippocampus (Figure 1).

In the rat liver, there were cytoplasmic vacuolization, clear cell foci, and eosinophilic hepatocytes (Figure 2).

The number of neuroglia and hepatic clear cells were counted in the entire field of view of each preparation. Administration of soursop leaf extract for 90 days resulted in a significant mean increase in hepatic clear cells and brain neuroglia in the treatment group in comparison with the control group, except in the hippocampus and substantia nigra (Table 1).

\section{DISCUSSION}

The interesting thing about this study is the increase in neuroglia in the nucleus accumbens and cerebral cortex. In contrast, there was no increase in neuroglia in the substantia nigra and the hippocampus of the rats.

Increased neuroglia (gliosis) occurs when neurons undergo necrosis. The necrotic neurons will be surrounded by neuroglia. This relates to the function of neuroglia as supporter cells. The results of this study showed that aqueous soursop leaf extract given orally for 90 days had not been able to cause necrosis in the rat substantia nigra. The damage in the substantia nigra neurons only reached the stage of degeneration. This is supported by microscopic findings in substantia nigra neurons in the form of cytoplasmic vacuolization. Similarly there was neuronal cytoplasmic vacuolization in the hippocampus.

This is understandable given the strength of acetogenin compounds in soursop plants. The leaves of Annona muricata contain neurotoxic

Table 1. Mean number of hepatic clear cells and brain neuroglia, by treatment group

\begin{tabular}{lccc}
\hline & \multicolumn{2}{c}{ Treatme nt } & p \\
\cline { 2 - 3 } & So usop ex tract & Control & $0.029^{*}$ \\
\hline Hepatic clear cells(\%) & $12.70 \pm 6.18$ & $3.80 \pm 1.92$ & $0.015^{*}$ \\
Brain neurogia (\%) & & & 0.174 \\
Cerebral cor tex & $18.21 \pm 3.47$ & $12.38 \pm 2.37$ & 0.353 \\
Hippocampus & $11.13 \pm 4.25$ & $7.70 \pm 2.83$ & $0.03^{*}$ \\
Substantia niga & $11.59 \pm 1.52$ & $11.00 \pm 1.22$ & $15.22 \pm 4.66$ \\
Nucleus accumbens & $22.90 \pm 4.70$ & &
\end{tabular}


isoquinolinic alkaloids and acetogenins. Isoquinolinic alkaloids can damage dopaminergic neurons and non-dopaminergic neurons (GABAergic). Annonacin, an acetogenin compound that is present in soursop leaves, is able to passively diffuse into the cell. This compound is 50 times more toxic to dopaminergic neurons and 2000 times more toxic to non-dopaminergic neurons, when compared with 1-methyl-4phenylpyridinium (MPP). ${ }^{(12,13)}$ The substantia nigra is a brain structure that is rich in dopaminergic neuronal cell bodies. These findings raise the possibility that the acetogenins in aqueous soursop leaf extract preferentially affect non-dopaminergic neurons as compared to dopaminergic neurons. This supports the findings in this study where the nucleus accumbens and cerebral cortex have more severe damage resulting in gliosis compared with the substantia nigra and the hippocampus, which merely undergo a process of degeneration characterized by cytoplasmic vacuolization of rat neurons.

The results are consistent with research findings by Champy et al. ${ }^{(13)}$ of severe degeneration of dopaminergic neurons in the substantia nigra in the form of cytoplasmic vacuolization upon administration of purified annonacin for 28 days, giving rise to symptoms of Parkinson's disease in rats. Degenerating neurons showed a picture of dystrophy and enlargement of the nerve fibers, and swelling of the nucleus.Acetogenins and alkaloids contained in the plant soursop are able to damage dopaminergic neurons. Various studies at the cellular as well as community level have demonstrated the neuronal damage after administration of this compound. ${ }^{(14,15)}$ Neuronal necrosis occurs after repeated exposure to neurotoxins. The term necrosis can be used to describe the state of ischemic neurons. The cell body will shrink due to reduced neuronal cell cytoplasm. In HE staining, the cell body will appear eosinophilic. The final stage of degeneration, neuronal necrosis, will appear in the form of changes to the nucleus as karyorrhexis or karyolysis. These changes can be observed by using a light microscope. Necrotic neurons will be surrounded by glia (gliosis). Cellular mechanisms underlying neurodegeneration involve the accumulation of tau protein in the cytoplasm of dopaminergic neurons. Tau is a microtubule-associated protein (MAP) located in the axon. The presence of microtubular damage stimulated by ATP upon the administration of annonacin causes tau protein to accumulate in the cytoplasm of dopaminergic neurons. ${ }^{(12)}$

The ability of acetogenins to damage dopaminergic neuronal cell bodies in the area ventralis tegmenti and the substantia nigra will indirectly affect the neurons in the nucleus accumbens. Dopaminergic neurons project to the nucleus accumbens so that in the event of damage or cell death of dopaminergic neurons in the area ventralis tegmenti or substantia nigra, it will affect the neurons in the nucleus accumbens. ${ }^{(16,17)}$ The toxic effect of soursop leaves may also be due to its alkaloid content. Mohanty found that the imino sugar alkaloid swainsonine has neurotoxic properties. Swainsonine is a mannosidase inhibitor that exert neurotoxic effects by inhibition of lysosomal acidic alpha mannosidase. The swainsonine content of soursop leaves is $0.0004 \%$ of their dry weight. If consumed in amounts of $0.001 \%$ of the diet, the compound may cause neurological disorders. ${ }^{(17)}$ Other soursop alkaloids are 1 benzyl-1,2,3,4-tetrahydroisoquinoline (1BnTIQ) and annonamine. The compound 1BnT1Q can demonstrably induce symptoms of parkinsonism in experimental animals. Annonamine is neurotoxic for cathecholaminergic neurons, thus inducing parkinsonism. ${ }^{(18)}$ The toxic effects of soursop in humans have been reported previously. It is said that there is a relationship between consumption of soursop products and brain atrophy with enlargement of the cerebral ventricles. $^{(19)}$

The microscopic picture of hepatic focal lesions can be seen in the cytoplasm of hepatocytes. On the basis of hematoxylin-eosin 
staining, hepatic focal lesions can be divided into the following types: basophilic, eosinophilic, clear cell, or mixed. The results of this study indicate the presence of clear and acidophilic cell foci. A clear cell focus is characterized by swelling of hepatocytes, followed by an increase in the size of the nucleus.

All drugs of any kind either herbal, natural, or synthetic can give side effects to various organs, among which the liver is the center of drug metabolism and detoxification. ${ }^{(20)}$ Nascimento et al. ${ }^{(7)}$ in their study on the effects of Annona coriacea (araticum) found that the ethanol extract of the plant can cause hepatotoxicity. Hepatotoxicity is determined by a decrease in the number of cells per area, changes in the morphology of hepatocyte nuclei cytoplasmic vacuolization, and decreased appetite. There are two theories regarding the mechanism of liver damage induced by acetogenin. The first theory is through the mechanism of adaptation of the liver to the burden of acetogenin metabolism. The liver is the organ most frequently damaged. Around $80 \%$ of the liver blood supply comes from the hepatic portal vein that drains blood from the gastrointestinal system. Toxic substances including those from plants, fungi, and bacteria, and also metals, minerals and other chemical substances that are absorbed into the portal blood system are carried toward the liver as the center of drug metabolism.

The second theory is through a direct mechanism of acetogenin on hepatocytes, because hepatocytes have mitochondria. Acetogenin which is the active compound contained in soursop inhibits mitochondrial complex I activity and is likely to cause side effects. But the complete explanation is not known with certainty. ${ }^{(21)}$

Subacute treatment with A. muricata aqueous extract for 14 days had no effect on the weights of the liver, kidneys, heart and stomach, while the uterus increased in weight to $1000 \mathrm{mg} /$ $\mathrm{kg}$ and beyond. Hematological parameters, ALT, AST, ALP, urea and albumin were unaffected while creatinine levels were increased at 2500 mg. ${ }^{(22)}$

A limitation of this study was the use of a single dose of aqueous soursop leaf extract, thus precluding the determination of the minimal dose that can cause damage to healthy cells. The study results demonstrate that soursop leaves are not completely safe when used as herbal medication, since it can cause injury to healthy cells. Consumers of soursop leaves will hopefully pay attention to the dose and duration of administration, in order to prevent the side effects of degeneration and necrosis of healthy cells. Further studies are indicated to determine the minimal dose and duration of administration that can induce degeneration and necrosis of healthy cells.

\section{CONCLUSION}

An aqueous extract of soursop (Annona muricata) leaves given orally increases the numbers of neuroglia in the cerebral cortex and nucleus accumbens of the brain and the number of hepatic clear cells in rats.

\section{ACKNOWLEDGEMENTS}

The authors are indebted to UPPM Medical Faculty, Islamic University of Indonesia, for supporting this study.

\section{REFERENCES}

1. Moghadamtousi SZ, Kadir HA, Paydar M, et al. Annona muricata leaves induced apoptosis in A549 cells through mitochondrial-mediated parhway and involvement of NF-kB. Complement Alt Med 2014;14:299.

2. Mishra S, Ahmad S, Kumar N, et al. Annona muricata (The cancer killer): a review. Global J Pharm Res 2013;2:1613-8.

3. Liaw CC, Wu TY, Chang FR, et al. Historic perspectives on annonaceous acetogenins from the chemical bench to preclinical trials. Planta Med 2010;76:1390-404.

4. Pott LF, Luzzio FA, Smith SC, et al. Annonacin in Asimina triloba fruit: implication for 
neurotoxicity. Neurotoxicol 2012;33:53-8. doi: 10.1016/j.neuro.2011.10.009.

5. Hollerhage M, Matusch A, Champy P, et al. Natural lipophilic inhibitors of mitochondrial complex I are candidate toxins for sporadic neurodegenerative tau pathologies. Exp Neurol 2009;220:133-42.

6. Yamada ES, Respondek G, Mussner S, et al. Annonacin, a natural lipophilic mitochondrial complex I inhibitor, increases phosphorylation of tau in the brain of FTDP-17 transgenic mice. Exp Neurol 2014;253:113-25.

7. Nascimento GNL, Valadares MC, Nishijo H, et al. Investigation of the toxic potential of crude ethanol extract of Annona coriacea (araticum) seeds in acute exposed mice. Brazilian $\mathrm{J}$ Pharmacog 2012;22:580-6.

8. Alvarez CO, Neske A, Chahboune N, et al. Ucupentol, a novel mono-tetrahydrofuranic acetogenin from Annona montana, as a potent inhibitor of mitochondrial complex I. Chem Biodivers 2009;6:335-40.

9. Dayeef AY, Karyono S, Sujuti H. The influence of Annona muricata leaves extract in damaging kidney cell and inducing caspase-9 activity. J Pharm Biol Sci 2013;8:48-52.

10. Li K, Li Q, Li J, et al. Alkaloid from angelicae daharaicae inhibits hela cell growth by inducing apoptosis and increasing cascape-3 activity. Lab Med 2008;399:540-6.

11. McMartin DN, O’Donoghue JL, Morrissey R, et al, editors. Non-proliverative lesions of the nervous system in rats, NS-1. In: Guides for toxicologic pathology. Washington, DC: STP/ ARP/AFIP;1997.p.51-76.

12. Escobar-Khondiker M, Hollerhage M, PauleMuriel M, et al. Annonacin, a natural mitochondrial complex I inhibitor, causes Tau pathology in cultured neurons. J Neurosci 2007; 27:7827-37.
13. Champy P, Melot A, Guérineau V, et al. Quantification of acetogenins in Annona muricata linked to atypical parkinsonism in Guadeloupe. Mov Disord 2005;20:1629-33.

14. Shaw CA, Hoglinger GU. Neurodegenerative disease: neurotoxins as sufficient etiologic agent? Neuromol Med 2008;10:1-9.

15. Arif IA, Khan HA. Environmental toxins and parkinson's disease: putative roles of impaired electron transport chain and oxidative stress. Toxicol Ind Health 2010;26:121-8. doi: 10.1177/ 0748233710362382.

16. Richard JM, Berridge KC. Nucleus accumbens dopamine/glutamate interaction switches modes to generate desire versus dread: D1 alone for appetitive eating but D1 and D2 together for fear. J Neurosci 2011;31:12866-79.

17. Mohanty S, Hollinshead J, Jones L, et al. Annona muricata (Graviola): toxic or therapeutic. Natural Product Comm 2008;3:31-3.

18. Matsushige A, Kotake Y, Matsunami K, et al. Annonamine, a new aporphine alkaloid from the leaves of Annona muricata. Chem Pharm Bull 2012;60:257-9.

19. Lannuzel A, Hoglinger GU, Verhaeghe S, et al. Atypical parkinsonism in Guadeloupe: a common risk factor for two closely related phetotypes? Brain 2007;130:816-27.

20. Warisno DK. Daun sirsak: langkah alternatif menggempur penyakit. Jakarta: Gramedia Pustaka Utama;2012.

21. Lim TK. Edibel medicinal and non-medicinal plants. Fruits 2012;1. doi: 10.1007/978-90-4818662-7_1.

22. Arthur FKN, Woode E, Terlabi EO, et al. Evaluation of acute and subchronic toxicity of Annona Muricata (Linn.) aqueous extract in animal. Eur J 2011;4:115-24. 